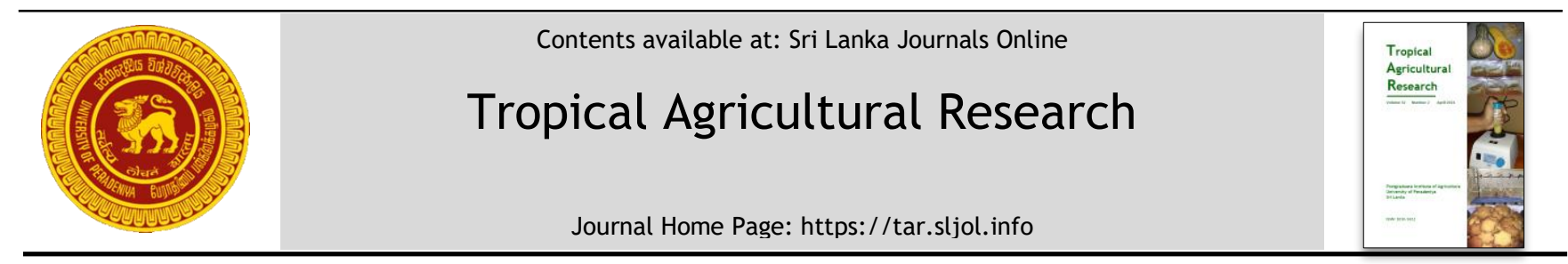

\title{
Occurrence of bioactive health promoting compounds in commercial products of mango, pineapple and wood apple in Sri Lanka
}

\author{
P.C. Arampath ${ }^{1 *}$, Matthijs Dekker ${ }^{2}$ and D.A.N.Dharmasena ${ }^{3}$ \\ ${ }_{1}^{1}$ Department of Food Science and Technology, Faculty of Agriculture, University of Peradeniya, Peradeniya, Sri Lanka. \\ ${ }^{2}$ Food Quality and Design Group, Department of Agrotechnology and Food Sciences, Wageningen University, \\ Wageningen, the Netherlands. \\ ${ }^{3}$ Department of Agricultural Engineering, Faculty of Agriculture, University of Peradeniya, Peradeniya Sri Lanka.
}

\section{ARTICLE INFO}

\section{Article history:}

Received: 23 November 2020

Revised version received:1 February 2021

Accepted: 11 March 2021

Available online: 1 April 2021

\section{Keywords:}

Antioxidant activity

Cordial

Fruit processing

Nectar

Phytochemicals

\section{Citation:}

Arampath, P.C., Matthijs Dekker. and Dharmasena, D.A.N. (2021). Occurrence of bioactive health promoting compounds in commercial products of mango, pineapple and wood apple in Sri Lanka. Tropical Agricultural Research, 32(2): 243-255

DOI: http://doi.org/10.4038/tar.v32i2.8471

Arampath P.C. (iD

https:// orcid.org/0000-0003-4471-9343

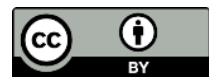

\section{ABSTRACT}

Bioactive health promoting compounds are present in foods that provide health benefits beyond their nutritional value. Processing of fruits into products can have significant consequences on the nutritional composition. This research was conducted to determine the compositional variation of vitamin C, total phenolic content (TPC), antioxidant activity (DPPH Radical Scavenging assay), $\beta$-carotene, total soluble solids ( ${ }^{\circ} \mathrm{Bx}$ value) and acidity in nectar, cordial and jam processed using ripe mango, pineapple and wood apple. Vitamin $\mathrm{C}$ content in unfortified cordials was $6.8 \pm 0.6$ and $8.5 \pm 1.2 \mathrm{mg} / 100 \mathrm{~g} \mathrm{FW}$ for pineapple and wood apple respectively. However, vitamin $\mathrm{C}$ content in fortified cordials was comparatively higher in mango (56.7-67.6 mg/100g FW), pineapple (44.5-54.6 mg/100g FW) and wood apple $(49.9 \mathrm{mg} / 100 \mathrm{~g} \mathrm{FW})$ respectively. TPC in nectars ranged from 1.0-4.0 mg tannic acid equivalent (TAE)/100g FW (mango), 2.4-3.8 mg (TAE)/100g FW (pineapple) and 0.7-2.3 mgTAE/100g FW (wood apple) respectively whereas it was 3.34.9 mgTAE/100g FW (mango), 2.4-5.3 mgTAE/100g FW (pineapple) and 1.3-4.7 mgTAE/100g FW (wood apple) in cordials. TPC in jam was higher than nectar and cordial products due to incorporation of $40 \%$ fruit pulp in jams. The antioxidant activity in nectar was within the range of 0.23-0.40 (mango), 0.29-0.38 (pineapple) and 0.21-0.38 (wood apple) $\mu$ molTrolox g${ }^{1} \mathrm{FW}$. The antioxidant activity was not correlated with vitamin $\mathrm{C}$ or TPC while total soluble solids vs dry weight was highly correlated $\left(\mathrm{R}^{2}=0.98\right)$. A substantial amount of $\beta$-carotene was measured in mango and pineapple products while $\beta$-carotene was not detected in wood apple products. The ways of minimizing the potential influential factors along the supply chain is yet to be investigated in broader perspective. It is recommended to promote cultivation of new fruit varieties rich in nutrients, designing new industrial fruit processing technologies including non-thermal processing techniques to minimize the loss of bioactive phytochemicals.

*Corresponding author: pcarampath@gmail.com 


\section{INTRODUCTION}

The consumption of tropical fruits has gradually increased over the years as these fruits provide high amounts of antioxidants and other health benefits (Ahn et al., 2020). Fruits are naturally rich in sugar, fiber, vitamin $\mathrm{C}$ and phytochemicals. Dietary recommendations and consumer awareness programs across the world on potential health benefits of fruits and vegetables against various chronic diseases is being implemented (Aune et al., 2017; Wallace et al., 2020). There are more than 5000 dietary bioactive compounds identified to date and the most of these compounds possess substantial benefits to human health (Gonzalez-Gallego et al., 2010; Gonzalez-Vallinas et al., 2013: Liub, 2013; Casas et al., 2018). The available dietary bioactive compounds and their quantities are growing concerns of the consumers in choosing fruits and vegetables (Wallace et al., 2020).

Mango is rich in an array of bioactive compounds, high amounts of antioxidants, polyphenols, a blend of sugar $(16-18 \% \mathrm{w} / \mathrm{v})$ and carotene, as vitamin A (Pace et al., 2014; Schreinemachers et al., 2018). Vitamins, minerals and micronutrients available in pineapple play an important role in the human diet. Fruits with substantial quantities of flavonoids, polyphenols, vitamins, minerals and other secondary metabolites are more preferred than the exotic taste (Da Silva et al., 2014). Recent scientific epidemiological evidences revealed an association between consumption of foods rich in phytochemicals and reduction of risk of diseases such as cancer, cardiovascular diseases, inflammation, diabetes, cataracts, neurodegenerative diseases, and hypercholesterolemia (Tanaka et al., 2012; Liub, 2013; Colijn et al., 2017; Crowe-Whit et al., 2017).

Products with high amylose content induce lower blood glucose and insulin responses compared to amylopectin. Glycaemic Indices of thirteen tropical fruits ranging from 28 (African star apple) to 68 (watermelon) and a correlation between phenols and antioxidant activity were reported by Oboh et al., in 2015.

Identification, quantification and isolation of specific phytochemicals in pulps and by-products of tropical fruits for nutraceutical supplements, dietary additives, novel foods and pharmaceutical products were reported by many authors (Ayala-Zavala et al., 2011; Da Silva et al., 2014). The relative contribution of different fruit and vegetable products and the components in them (phytochemicals) to health benefits is still a topic of investigation. The food supply chain has been shown to have a large variation in the levels of various phytochemicals (Dekker et al., 2000). Due to different conditions and processes in the supply chain, there is a large effect on the final health benefits for the consumer (Dekker and Verkerk, 2003).

Like many other tropical countries, Sri Lanka also produces many tropical fruits. These fruits are available for consumers in fresh, minimally processed, and processed forms. Due to the seasonal nature of availability of these fresh fruits, processed products with an extended shelf life have emerged in the market in the form of juice, nectar, cordial, jam, canned and dehydrated fruits. Analysis of potential health promoting compounds such as vitamin C, carotenoids, flavonoids and antioxidant activity of many fresh fruits and vegetables have extensively been studied during the last decade, including several processed products (Malta et al., 2013). However, the information on tropical fruits and especially processed products of tropical fruits in Sri Lanka is scarce.

Mango (Mangifera indica L.), pineapple (Ananas comosus L. Marril) and wood apple (Limonia acidissima L.) are highly popular fruits in many tropical countries and the demand for these fruits and processed products exists throughout the year. Wood apple is consumed as homemade or industrially processed drinks or jam. Mango and pineapple processed products include juice, nectar, cordial, canned slices in syrup or in juices, jam, chutney, dehydrated pieces and fruit leathers. Exportation of tropical fruits in fresh forms is a common method. However, exportation of mango and pineapple juice to nontropical countries is usually in the form of concentrates (Somsri, 2014; Arampath and Matthijs, 2019). Different tropical and nontropical fruit juices are often combined to produce mixed juices, nectars and cordials with commercial attractive aroma, colour and flavour combinations.

Processing of tropical fruits into various products can have significant consequences on the nutritional composition of these products. This will have an impact on the potential health promoting properties. Loss of phytochemicals and nutrients can occur due to thermal processes, separation of parts of the fruit matrices and by dilution with sugar solutions. This could lead to substantial deviations in health beneficial phytochemicals in the processed fruit products.

The agricultural practices, climatic/soil conditions, postharvest handling and processing methods are influenced on the composition of 
mango fruit and processed products (Ali et al., 1992; Siddiq et al., 2012). The intensity of some influential intrinsic or extrinsic factors can be manipulated along the supply chain to remain substantial quantities of health promoting compounds. The information on compositional variation in commercial fruit-based products in Sri Lanka is scanty. Therefore, this research was conducted to determine the compositional variation of vitamin C, total polyphenolic content, antioxidant activity (DPPH Radical Scavenging assay), $\beta$-carotene, total soluble solids $\left({ }^{\circ} \mathrm{Bx}\right.$ value) and acidity in nectar, cordial and jam processed using ripe mango, pineapple and wood apple. This research finding is useful in reformulating the ingredients, process designing to improve the potential health beneficial compounds in commercial fruit-based products, to statutory and regulatory bodies, nutritionists and for consumer awareness of the processed fruit-based products.

\section{METHODOLOGY}

\section{Commercial Fruit Products}

Commercially available pulp or juice-based products of mango, pineapple and wood apple, were selected based on the availability throughout the country. The samples of bottled nectar $(190 \mathrm{~mL})$, cordial $(750 \mathrm{~mL})$ and jam $(450$ g) were purchased directly from five leading fruit processing industries (names are non-disclosed) with the manufacturing date not more than 10 days. Samples of the juice products were prepared shaking the bottles thoroughly and filtering through previously washed and then dried muslin cloth to remove traces of objectionable solid particles. The samples of jam were blended and mixed thoroughly to assure the homogeneity.

\section{Chemicals}

Dichlorophenol-indophenol (DCP), FolinCiocalteu's reagent, $\mathrm{Na}_{2} \mathrm{CO}_{3}, \beta$-carotene (Merck, Germany), sodium sulphate, 1,1-diphenyl-2picrylhydrazyl (DPPH), tannic acid (SigmaAldrich, Germany), methanol, tetrahydroxyfuran (THF) (BioSolve, The Netherlands), and oxalic acid, magnesium carbonate and L-ascorbic acid (HiMedia, India) were used for the chemical analysis.

\section{Ascorbic Acid}

A sample (5 g) of nectar or cordial was homogenized with $0.25 \%$ oxalic acid solution (2$3 \mathrm{ml}$ ) and centrifuged at $4000 \mathrm{rpm}$ for $15 \mathrm{~min}$. The supernatant was transferred into a $50 \mathrm{~mL}$ volumetric flask and brought up to the mark with
$0.25 \%$ oxalic acid solution. An aliquot of $10 \mathrm{~mL}$ solution was pipetted into a $250 \mathrm{~mL}$ conical flask and titrated against 2, 6 dichlorophenolindophenol (DCP) dye until colour changed to pink. DCP dye was standardized with $10 \mathrm{~mL}$ of standard ascorbic acid solution $200 \mathrm{mg} \mathrm{L}$ Ascorbic acid in $250 \mathrm{~mL}, 0.25 \%$ oxalic acid solution). Dye equivalents (mg ascorbic acid required to neutralize $1 \mathrm{~mL}$ of dye solution) were calculated (AOAC, 2000).

\section{Total phenolics}

Total phenolics were analysed by using the FolinCiocalteu's reagent as described by Singleton et al., (1998). Water extract of the phenolic compounds of the sample (5 g sample with 7.5 $\mathrm{mL}$ water) was prepared and filtered. The filtered sample was centrifuged at $4000 \mathrm{rpm}$ for 15 min and supernatant was taken for analysis. The supernatant $(1 \mathrm{~mL})$, demi-water $(5 \mathrm{~mL})$ and Folon-Ciocalteu's reagent $(1 \mathrm{~mL})$ were pipetted into volumetric flask $(25 \mathrm{~mL})$ and mixed well. Subsequently, saturated $\mathrm{Na}_{2} \mathrm{CO}_{3}$ solution $(1 \mathrm{~mL})$ was added and mixed well. Finally, the volume was adjusted to $25 \mathrm{~mL}$ with demi-water and swirled the flask several times. Measurement of absorbance of the prepared solution was done using a spectrophotometer at $725 \mathrm{~nm}$ after 15 min. A calibration curve was prepared using tannic acid and values were expressed as tannic acid equivalents, mg TAE/100 g FW (fresh weight).

\section{Antioxidant Activity}

The free radical scavenging capacity of the different compounds in the samples was measured using DPPH (1,1-diphenyl-2picrylhydrazyl) assay explained by SánchezMoreno, et al., (1998) and later modified by Jiménez-Escrig et al., (2000) for measuring lipophilic compounds. A dilution series of the samples of processed fruit products was prepared in methanol.

DPPH, $236 \mathrm{mg}$ was dissolved in $100 \mathrm{~mL}$ methanol; $10 \mathrm{~mL}$ aliquots of this solution were prepared and stored at $0{ }^{\circ} \mathrm{C}$. A working solution $\left(6 \times 10^{-5} \mathrm{M}\right)$ was prepared by diluting the stock solution 100 times in methanol. A standard curve for DPPH was developed using a series of DPPH concentrations in methanol. The absorptions were measured at $515 \mathrm{~nm}$. DPPH solutions $\left(6 \times 10^{-5} \mathrm{M}, 3.9 \mathrm{~mL}\right)$ were taken into the cuvette, and then $0.1 \mathrm{~mL}$ of sample was added, kept in dark at $23 \pm 1{ }^{\circ} \mathrm{C}$ for $30 \mathrm{~min}$ and measured at 515 nm. Trolox was the reference standard antioxidant. The amount of DPPH not reacted was determined using the DPPH standard curve. Efficiency Coefficient $\left(E_{50}\right)$, the amount of 
sample (dry weight) necessary to reduce the initial DPPH concentration by $50 \%$ was determined in comparison to trolox. The antioxidant capacity was expressed as Trolox Equivalent Antioxidant Capacity (TEAC) $\mu \mathrm{mol} / \mathrm{g}$ FW.

\section{$\beta$-Carotene}

$\beta$-Carotene content was determined by Reversed Phase High Performance Liquid Chromatography (RP-HPLC). The HPLC instrument (SHIMADZU, CTO-10A vp) consisted of a Vydac 218TP54 ( $\mathrm{C}_{18}$, $5 \mu \mathrm{m}, 4.6 \mathrm{~mm}$ ID $\times 250 \mathrm{~mm}$ ) reversed phase analytical column with a guard column. The extraction method of $\beta$-carotene was a slightly modified method (Bushway,1985; Bushway and Wilson, 1992).

Extraction was carried out under red dimmed light, while flushing with nitrogen to minimize oxidation. Two grams of sample with $4 \mu \mathrm{L} 0.1 \%$ Butylated Hydroxy Toluene (BHT) in ethanol were combined with $1.0 \mathrm{~mL}$ of internal standard, $\beta$-apo-8-carotenal $\quad 0.08 \quad \mathrm{mg} / \mathrm{mL} \quad$ in tetrahydroxyfuran (THF). Thereafter $4 \quad \mathrm{~g}$ anhydrous sodium sulfate, $0.5 \mathrm{~g}$ magnesium carbonate and $30 \mathrm{~mL}$ of THF were added. The suspension was mixed by vortexing for one minute, at $1200 \mathrm{rpm}$ and the mixture was allowed to precipitate to a clear supernatant. This supernatant was filtered through a filter paper (Whatman No.1) into a $250 \mathrm{~mL}$ roundbottom flask. Then, $20 \mathrm{~mL}$ THF were added to the remaining precipitate, and extracted as described previously. This procedure was repeated thrice until the filtrate and residue were colourless. The filtrate was concentrated until near dryness by a vacuum rotary evaporator ( 40 ${ }^{\circ} \mathrm{C}, \pm 260$ mbar) and flushed with nitrogen. Subsequently, the concentrate was dissolved in $10 \mathrm{~mL}$ methanol: THF mixture (3:1) containing $0.01 \%$ BHT. An aliquot of $1 \mathrm{~mL}$ was filtered through a $0.45 \mu \mathrm{m}$ PTFE HPLC syringe filter (Alltech, DeerfieldIL) into a vial prior to HPLC injection.

The eluent, composed of $92.5 \%$ methanol, $7.5 \%$ THF and $0.1 \%$ triethylamine, was degassed by an All-Tech degassing system. A series of samples and standard solutions of $20 \mu \mathrm{L}$ each were injected into the column, and eluted using isocratic mode for 25 minutes with a flow rate of $1.0 \mathrm{~mL} / \mathrm{min}$. $\beta$-Carotene was identified by internal standard ( $\beta$-apo-8-carotenal) and quantified by spectrum and peak area.

\section{Total Soluble Solids (TSS)}

TSS were determined using a hand-held refractometer (ATAGO, Japan) and expressed as Brix $\left({ }^{\circ} \mathrm{Bx}\right)$ value.

\section{Titratable Acidity}

An aliquot of blended and filtered sample was titrated against $0.1 \mathrm{~N}$ sodium hydroxide solution with phenolphthalein indicator (AOAC, 2000). Acidity of highly coloured juices (mango or wood apple) was determined by titrating the sample with known volume of distilled water until the colour change of the sample.

\section{Dry Matter Content}

The dry matter content was determined by using the oven drying method. Fruit juice samples of 3$4 \mathrm{~g}$ were drawn into labelled moisture cans and 1 g sea-sand was added and mixed them using a spatula, heated with the lid open overnight at 80 ${ }^{\circ} \mathrm{C}$ followed by 3 hours drying at $105^{\circ} \mathrm{C}$. Samples were cooled in a desiccator prior to weighing the cans.

\section{Statistical Analysis}

One-way Analysis of Variance (ANOVA) at 0.05 significance level $(\alpha=0.05)$ was conducted using Minitab-15 version followed by Tukey pairwise comparisons at $95 \%$ Confidence. Values measured from triplicate samples were subjected to the analysis. Correlation coefficient $\left(\mathrm{R}^{2}\right)$ was determined by linear regression analysis using MS Excel-2017 vision.

\section{RESULTS AND DISCUSSION}

Dry weight, total soluble solid (TSS), acidity, vitamin $\mathrm{C}$, TPC, $\beta$-carotene, and antioxidant activity measured in commercial products (nectar, cordial, jam) using mango, pineapple and wood apple are given in Table 1.

\section{Dry Matter Content, Acidity and Total Soluble Solids}

The variability of dry matter, acidity and TSS is substantially lower in processed products of mango, pineapple and wood apple. The dry matter content of mango, pineapple and wood apple nectars varied between 15.3 - 19.4\%, whereas in cordial and jam, it was $49.9-60.8 \%$ and $68.2-73.6 \%$ respectively (Table 1 ). The variation of dry matter content within the same product categories of three fruits was significantly different $(\mathrm{P}<0.05)$ among the fruit processors except for pineapple nectar and cordial. In commercial operations, percentage fruit pulp or juice content in the same product formulation varied among the fruit processors. Therefore, fruit pulp or juice content in the formulation has a direct impact on dry matter content of the product. Similarly, acidity in nectar varied between $0.27-0.52 \%$, whereas in cordial 
and jam the variation was $0.31-0.69 \%$ and 0.62 $0.92 \%$, respectively (Table 1 ). According to the government regulation in Sri Lanka, Sri Lanka Standard (SLS) product certification is compulsory for the marketable products of nectar (SLS 729:2010) and cordial (SLS 214:2010 - fresh fruit cordials). The SLS standard (SLS 729:2010) requirements for nectar are TSS 16\% w/w (maximum) and acidity (as anhydrous citric acid) $1 \% \mathrm{w} / \mathrm{w}$ (maximum) respectively. The similar limits specified for cordial are TSS $48^{\circ} \mathrm{Bx}$ and acidity $1 \% \mathrm{w} / \mathrm{w}$ (SLS 214:2010). TSS in jam is not less than $65 \%$ by mass (SLS 265:2011) while minimum fruit content is not less than $40 \%$. SLS logo is not compulsory for commercial products of jam. TSS value of mango, pineapple and wood apple jam was within $62-66 \%$ in the tested sample and the values were not significantly different $(P>0.05)$ except in the product band A (Table 1). TSS and acidity limits of the analyzed commercial products of nectar and cordial fulfilled the SLS compulsory product standards.

In tested samples, dry weight and acidity values were significantly different $(\mathrm{P}<0.05)$ within the same product category. TSS in each commercial brand was significantly different $(\mathrm{P}<0.05)$ except in mango cordial and jam. TSS and acidity are the key chemical parameters specified in the SLS standards in fruit-based products. The most of the commercial fruit-based products are formulated to fulfil these key parameters, TSS and acidity while neglecting the attention on health promoting phytochemicals unintentionally. Further, nutritional composition in the product label is confined to the major constituents of foods and energy value. Because of this reason, consumer perception on health beneficial compounds and trust on experimented product categories are greatly influenced.

Fresh fruit pulp or juice is processed into products during the peak season of fruits. The thermally and/or chemically processed bulk preserved pulp or juice in single strength or concentrated forms are stored at ambient, cold or frozen storage (Arampath and Matthijs, 2019). These semi-processed bulk preserved juice or pulp are mainly used during the off season or exported as the raw material. Formulation of fruit-based products is mainly calculated using TSS, acidity, fruit content and sensory attributes of the products. Attention on available health beneficial phytochemicals in fruit pulp or juice has been disregarded in product formulation. Thus, occurrences of these health beneficial compounds are unknown to the consumers. In this study, the result proved that despite the variation in variety, location of cultivation and certain environmental factors, there can be a huge variation in finished products during product formulation, raw material selection (fresh or bulk preserved forms) and process control parameters applied during the production by the fruit processors. Interestingly, the specified key indices (TSS, acidity) are well maintained to fulfil the products' standards. However, the utmost beneficial nutrients, the secondary metabolites, such as flavonoids are unavailable to the end users. Further, the health beneficial compounds in bulk stored fruit pulp or juice at cold storage $\left(4{ }^{\circ} \mathrm{C}\right)$ possessed substantially low or negligible amounts of health beneficial compounds than the fresh counterparts (Arampath and Matthijs, 2019).

Variation in sugar, ascorbic acid, organic acids, and TSS content in different varieties and cultivars of mango are reported by Liua, et al., (2013). In Sri Lanka, fructose content in mango

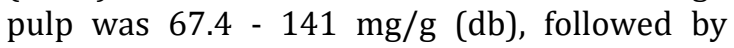
glucose and sucrose (Thanaraj et al., 2009). Variation in sugars, amino acids and hydroxymethylfurfural (HMF) in concentrated pineapple juice in different regions of the world has also been reported (Ooghe and Dresselaerts, 1995). TSS content in the finished product is mainly a sum of soluble sugars in fruit juice or pulp and the added sugar during mixing of ingredients.

Processing of pineapple mostly involves heat treatments resulting in variation in sensory and nutritional quality of the commercial products (Mohamed, 2014; Chua and Leong, 2020). Loss of vitamin C during heat treatment and nonenzymatic browning, the Maillard reaction after processing (Vollmer et al., 2020) are also documented.

Hydrolysis of starch increases the sugar content in climacteric fruits during ripening and results in better eating quality of mango. TSS has been increased from $9.1 \%$ to $17.3 \%$ while titratable acidity reduced from $0.6 \%$ to $0.2 \%$ during the ripening of mango. Saranwong et al., (2004) reported the sugar content in pineapple consists of nearly $50 \%$ sucrose, $33 \%$ fructose and $17 \%$ of glucose. A strong correlation between starch content and the eating quality of mango was reported by Padda et al., (2011).

Commercial pineapple juice, nectars, pineapple juice and juice concentrates consist of sucrose $(4.1 \pm 0.7 \mathrm{~g} / 100 \mathrm{~mL})$, fructose $(2.5 \pm 0.5 \mathrm{~g} / 100$ $\mathrm{mL})$ and glucose $(2.3 \pm 0.4 \mathrm{~g} / 100 \mathrm{~mL})$ in more or less similar concentrations (Cárnara et al., 1995). The energy value, acceptability and sensory perception of the juices and processed 
products are determined by the available sugar products.

TSS of nectars, cordial and jam made from three fruits (mango, pineapple and wood apple) were found to be in between 12.8 - 16.8, 45.5 - 49.8 and 61-66.9 ${ }^{\circ} \mathrm{Bx}$ respectively. TSS value in the SLS standard is $48{ }^{\circ} \mathrm{Bx}$ for cordial (SLS 214:1985) and $64{ }^{\circ} \mathrm{Bx}$ for jam (SLS 265:1985). In this study, deviations among the commercial branded products were observed (Table 1). Although the composition of these commercial products is regulated in juice-based products through the Sri Lanka Standards as compulsory requirement, the results of this experiments has proved that the tested marketable products did not conform to the SLS product specification.

\section{Ascorbic Acid Content}

Variation in sugar, ascorbic acid, organic acids, and TSS content in different varieties and cultivars of mango has previously been reported (Ali et al., 1992; Liua et al., 2013). In the present study, a significant variation in ascorbic acid content measured in different products was observed (Table 1). There is a considerable variation due to addition of different fruit fraction and fortification with vitamin $\mathrm{C}$. There is no clear relationship with the type of fruit even though levels in fresh fruit are increasing in the order: Mango > Pineapple > Wood apple. Therefore, the observed variation has been resulted mainly due to fortification. The product label provides evidence for the fortification.

Variation of vitamin $\mathrm{C}$ in fresh pineapple juice was 9.2 - $93.8 \mathrm{mg} / 100 \mathrm{~mL}$ (Achinewhu and Hart, 1994). The vitamin $C$ content in fresh pineapple juice $(84.2 \pm 9.6 \mathrm{mg} / 100 \mathrm{~mL})$ and commercial pineapple juice produced using the concentrate were varied from $8.5 \pm 1.4$ to $58 \pm 4.9 \mathrm{mg} / 100$ (Cárnara et al., 1995).

In nectar, vitamin $\mathrm{C}$ contents with minimum and maximum values were $1.3-37.4 \mathrm{mg} / 100 \mathrm{~g}$ FW (mango), 24.1-33.8 mg/100g FW (pineapple), and 3.7- $6.9 \mathrm{mg} / 100 \mathrm{~g}$ FW (wood apple), respectively. The standard limit for vitamin $C$ is not given in the SLS standards. The higher levels of vitamin $\mathrm{C}$ in commercial products were resulted due to fortification of vitamin $\mathrm{C}$ as indicated in labels.

Vitamin $C$ contents in unfortified cordials; $0.6 \pm 0.3 \mathrm{mg} / 100 \mathrm{~g}$ FW for mango, 6.8 \pm 0.6 $\mathrm{mg} / 100 \mathrm{~g}$ FW for pineapple, and $8.5 \pm 1.2$ $\mathrm{mg} / 100 \mathrm{~g} \mathrm{FW}$ for wood apple were significantly different $(\mathrm{P}<0.05)$ from that of fortified products. Vitamin $C$ in fortified cordials ranged from 56.7 $67.6 \mathrm{mg} / 100 \mathrm{~g}$ FW for mango, 44.5-54.6 mg/100g FW for pineapple and 46.1-48.9 mg/100g FW for wood apple. In jams, vitamin $C$ content varied, 45.1-63.9 mg/100g FW (mango), 4.3-61.2 (pineapple) and 38.8-63.2 mg/100g FW (wood apple). Results revealed that wood apple jam is a rich source of ascorbic acid due to high content of fruit pulp (40\%). However, wood apple nectar had low in vitamin $\mathrm{C}$ content. Mango cordials and jams, and wood apple jams were relatively high in vitamin C. Other product categories had variable quantities. Since only three samples of each category were analyzed in this experiment, no general conclusions could be drawn.

\section{Total phenolic content}

Phenolic content in mango, 56.0 \pm 2.1 mgGAE/100g FW (Luximon-Ramma et al., 2003) and in pineapple, $119 \pm 6.0 \mu \mathrm{mol} / \mathrm{g}$ (Vinson et al., 2001) were reported with obvious variations. In this research, total phenols in the processed products were substantially lower than the fresh or ripe fruits. Total phenolics in fresh pineapple juice, 36.2 $\pm 0.5 \mathrm{mg} \mathrm{GAE} / 100 \mathrm{~mL}$ (Mahdavi et al., 2010), 67.4 mg GAE/100mL (Lugas and Hóvári 2003) and commercial packaged fruit juice $35.7 \pm 0.3 \mathrm{mgGAE} / 100 \mathrm{~mL}$ (Mahdavi et al., 2010) were reported. Total phenols content of nectars made from mango, pineapple and wood apple ranged from $1.0-4.0,2.4-3.8$ and $0.7-2.3 \mathrm{mg}$ Tannic acid equivalent (TAE)/100g FW, respectively.

The phenol content for cordials were little higher than nectars and, 3.3-4.9 for mango, 2.4-5.3 for pineapple and 1.3-4.7 mg/100g FW for wood apple (Table 1). However, due to high fruit content $(40 \%)$ of jam, relatively higher values of total phenol were reported for commercial jams; 3.4-6.5 mgTAE/100g FW (mango), 3.9-7.2 mgTAE/100g FW (pineapple) and 4.2-7.0 mgTAE/100g FW (wood apple).

TPC in methanolic extracts of mango and pineapple pulp were $20.0 \pm 2.6$ and $21.7 \pm 45 \mathrm{mg}$ GAE $100 \mathrm{~g}^{-1}$ of dried fruits (Kuskoski et al., 2006). TPC in pineapple was 40.4 $\pm 1.0 \mathrm{mgGAE} 100 \mathrm{~g}$ 1 fresh dry total fruit (Sun et al., 2002) while in dry extract pineapple powder, TPC was $9.1 \pm 1.3$ mgGAE/g (de Oliveira et al., 2009) Therefore, the determined measured values of phenolic compounds in nectars, cordials and jams are extremely lower than the reported values by other authors. The reason would be loss of phenolic compounds during washing, cutting and processing at subsequent processing steps. The intensity of thermal treatment and exposure time fruit during the processing are the influential factors to reduce the phenoilc compounds. 
Table I. Dry weight, total soluble solid, acidity, vitamin C, total phenolic content, $\beta$-carotene, and antioxidant activity measured in mango, pineapple and wood apple in commercial products, nectar, cordial and jam.

\begin{tabular}{|c|c|c|c|c|c|c|c|c|c|}
\hline \multicolumn{2}{|c|}{ Product } & \multirow{2}{*}{$\begin{array}{l}\text { Industry } \\
\text { A }\end{array}$} & \multirow{2}{*}{$\begin{array}{l}\text { Dry weight (\%) } \\
18.5 \pm 0.4 \mathrm{a}\end{array}$} & \multirow{2}{*}{$\begin{array}{r}\left.\text { Brix ( }{ }^{\circ} \mathbf{B x}\right) \\
13.6 \pm 0.8 \mathrm{a}\end{array}$} & \multirow{2}{*}{$\begin{array}{l}\text { Acidity (\%) } \\
0.35 \pm 0.04 \mathrm{a}\end{array}$} & \multirow{2}{*}{$\begin{array}{c}\begin{array}{c}\text { Vitamin } \\
(\mathbf{m g} / \mathbf{1 0 0 g})\end{array} \\
35.8 \pm 1.6 \mathrm{a}\end{array}$} & \multirow{2}{*}{$\begin{array}{c}\text { TPC* mg } \\
\text { (TAE)/100g } \\
2.4 \pm 0.9 \mathrm{ab}\end{array}$} & \multirow{2}{*}{$\begin{array}{c}\begin{array}{c}\beta \text {-carotene } \\
\mu \mathrm{g} / \mathrm{g}\end{array} \\
\mathrm{al}<\mathrm{dl}-1.24\end{array}$} & \multirow{2}{*}{$\begin{array}{r}\begin{array}{c}\text { AOX }^{* *} \boldsymbol{\mu m o l} \\
\text { Troloxg }^{-1}\end{array} \\
0.38 \pm 0.01 \mathrm{a}\end{array}$} \\
\hline \multirow{9}{*}{ 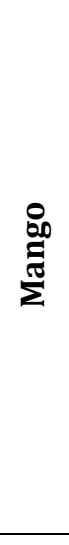 } & \multirow{3}{*}{ 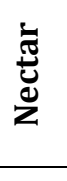 } & & & & & & & & \\
\hline & & B & $17.3 \pm 0.3 b$ & $14.5 \pm 1.2 \mathrm{a}$ & $0.28 \pm 0.01 \mathrm{~b}$ & $1.6 \pm 0.3 c$ & $1.2 \pm 0.2 b$ & $1.2 \pm 0.04$ & $0.24 \pm 0.01 c$ \\
\hline & & $\mathbf{E}$ & $15.9 \pm 0.6 c$ & $15.5 \pm 0.7 \mathrm{a}$ & $0.36 \pm 0.00 \mathrm{a}$ & $32.0 \pm 1.2 \mathrm{~b}$ & $3.2 \pm 0.8 \mathrm{a}$ & $\mathrm{al}<\mathrm{dl}-1.24$ & $0.33 \pm 0.01 b$ \\
\hline & \multirow{3}{*}{ ن } & $\mathbf{A}$ & $53.9 \pm 0.4 b$ & $48.5 \pm 0.9 a$ & $0.56 \pm 0.02 b$ & $58.0 \pm 1.3 b$ & $4.2 \pm 0.3 \mathrm{ab}$ & $1.35 \pm 0.08 \mathrm{a}$ & $0.56 \pm 0.02 \mathrm{a}$ \\
\hline & & C & $56.0 \pm 0.5 a$ & $46.8 \pm 0.1 b$ & $0.66 \pm 0.03 a$ & $61 \pm 1.3 b$ & $4.8 \pm 0.1 \mathrm{a}$ & $0.86 \pm 0.03 b$ & $0.52 \pm 0.04 a b$ \\
\hline & & D & $54.4 \pm 0.2 \mathrm{~b}$ & $48.0 \pm 01 \mathrm{ab}$ & $0.52 \pm 0.02 \mathrm{~b}$ & $66 \pm 1.6 a$ & $3.6 \pm 0.3 \mathrm{~b}$ & $1.24 \pm 0.25 \mathrm{ab}$ & $0.42 \pm 0.06 \mathrm{~b}$ \\
\hline & \multirow{3}{*}{ ఏ } & $\mathbf{A}$ & $71.1 \pm 0.8 a$ & $62.0 \pm 1.0 \mathrm{~b}$ & $0.72 \pm 0.02 b$ & $62 \pm 1.9 a$ & $3.8 \pm 0.5 b$ & $2.6 \pm 0.16 a$ & $0.47 \pm 0.02 \mathrm{a}$ \\
\hline & & C & $68.6 \pm 0.4 b$ & $65.0 \pm 1.0 \mathrm{a}$ & $0.83 \pm 0.02 \mathrm{a}$ & $46 \pm 0.9 c$ & $3.54 \pm 0.1 b$ & $1.54 \pm 0.11 b$ & $0.44 \pm 0.02 \mathrm{a}$ \\
\hline & & D & $70.5 \pm 0.1 \mathrm{a}$ & $66.0 \pm 0.9 \mathrm{a}$ & $0.76 \pm 0.01 \mathrm{~b}$ & $57 \pm 2.3 \mathrm{~b}$ & $6.2 \pm 0.3 \mathrm{a}$ & $1.2 \pm 0.05 \mathrm{c}$ & $0.37 \pm 0.01 b$ \\
\hline \multirow{9}{*}{ 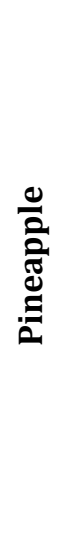 } & \multirow{3}{*}{ 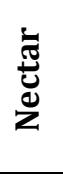 } & $\mathbf{A}$ & $16.13 \pm 0.2 \mathrm{a}$ & $14.6 \pm 0.9 a$ & $0.38 \pm 0.02 b$ & $32.5 \pm 1.3 \mathrm{a}$ & $2.8 \pm 0.4 a$ & $\mathrm{al}<\mathrm{dl}-0.64$ & $0.32 \pm 0.03 b$ \\
\hline & & C & $16.7 \pm 0.3 a$ & $15.6 \pm 0.7 \mathrm{a}$ & $0.49 \pm 0.03 a$ & $28.00 \pm 1.4 b$ & $3.2 \pm 0.6 \mathrm{a}$ & $0.85 \pm 0.06 a$ & $0.37 \pm 0.01 \mathrm{a}$ \\
\hline & & $\mathbf{E}$ & $16.4 \pm 0.5 \mathrm{a}$ & $16 \pm 0.8 \mathrm{a}$ & $0.32 \pm 0.03 \mathrm{~b}$ & $26.001 .9 \mathrm{~b}$ & $2.8 \pm 0.1 \mathrm{a}$ & $0.65 \pm 0.01 \mathrm{~b}$ & $0.35 \pm 0.01 \mathrm{ab}$ \\
\hline & \multirow{3}{*}{ 竺 } & B & $52.4 \pm 0.4 a$ & $49.0 \pm 0.9 a$ & $0.59 \pm 0.01 a$ & $6.8 \pm 0.6 c$ & $3.4 \pm 0.3 b$ & $1.10 \pm 0.05 a$ & $0.49 \pm 0.02 b$ \\
\hline & & D & $51.1 \pm 0.8 a$ & $48.5 \pm 1.2 \mathrm{a}$ & $0.35 \pm 0.04 b$ & $54 \pm 0.6 a$ & $2.5 \pm 0.1 \mathrm{c}$ & $1.20 \pm 0.35 a$ & $0.55 \pm 0.03 a$ \\
\hline & & $\mathbf{E}$ & $51.1 \pm 1.2 \mathrm{a}$ & $47.5 \pm 0.77 \mathrm{a}$ & $0.37 \pm 0.01 \mathrm{~b}$ & $46 \pm 1.5 b$ & $4.8 \pm 0.5 \mathrm{a}$ & $0.84 \pm 0.06 a$ & $0.43 \pm 0.02 c$ \\
\hline & \multirow{3}{*}{$\underline{\Xi}$} & B & $68.8 \pm 0.5 b$ & $64.0 \pm 0.8 a$ & $0.84 \pm 02 \mathrm{ab}$ & $4.8 \pm 0.5 c$ & $5.5 \pm 0.6 b$ & $1.80 \pm 0.06 a$ & $0.36 \pm 0.02 b$ \\
\hline & & C & $71.4 \pm 0.5 a$ & $63.5 \pm 1.0 \mathrm{a}$ & $0.86 \pm 0.03 a$ & $60.0 \pm 1.2 \mathrm{a}$ & $4.2 \pm 0.2 c$ & $1.20 \pm 0.08 a b$ & $0.42 \pm 0.03 a$ \\
\hline & & $\mathbf{E}$ & $69.4 \pm 0.4 b$ & $65.0 \pm 1.2 \mathrm{a}$ & $0.80 \pm 0.02 b$ & $52 \pm 3.2 b$ & $6.9 \pm 0.4 a$ & $0.86 \pm 0.06 b$ & $0.39 \pm 0.02 \mathrm{ab}$ \\
\hline
\end{tabular}


Table I. (Continued from the previous page) Dry weight, total soluble solid, acidity, vitamin C, total phenolic content, $\beta$-carotene, and antioxidant activity measured in mango, pineapple and wood apple in commercial products, nectar, cordial and jam.

\begin{tabular}{|c|c|c|c|c|c|c|c|c|c|}
\hline \multicolumn{2}{|c|}{ Product } & Industry & Dry weight (\%) & Brix $\left({ }^{\circ} B x\right)$ & Acidity (\%) & $\begin{array}{c}\text { Vitamin } \\
\text { (mg/100g) }\end{array}$ & $\begin{array}{c}\text { TPC* mg }^{*} \\
\text { (TAE)/100g }\end{array}$ & $\begin{array}{c}\beta \text {-carotene } \\
\mu \mathrm{g} / \mathrm{g}\end{array}$ & $\begin{array}{c}\text { AOX }^{* *} \mu \mathrm{mo} \\
\text { Troloxg-1 }^{-1}\end{array}$ \\
\hline \multirow{9}{*}{ 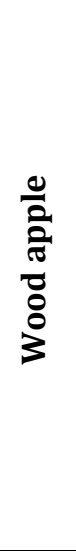 } & \multirow{3}{*}{$\begin{array}{l}\bar{\pi} \\
\stackrel{0}{0} \\
z\end{array}$} & $\mathbf{A}$ & $18.8 \pm 0.6 a$ & $15.6 \pm 1.0 \mathrm{a}$ & $0.45 \pm 0.04 \mathrm{a}$ & $6.4 \pm 0.5$ & $0.8 \pm 0.1 b$ & nd & $0.37 \pm 0.01 \mathrm{a}$ \\
\hline & & B & $17.6 \pm 0.2 b$ & $14.5 \pm 0.7 a$ & $0.38 \pm 0.02 b$ & $\mathrm{al}<\mathrm{dl}-3.7$ & $1.8 \pm 0.5 a$ & nd & $0.22 \pm 0.01 c$ \\
\hline & & C & $16.2 \pm 0.4 c$ & $14.0 \pm 0.8 \mathrm{a}$ & $0.46 \pm 0.01 \mathrm{a}$ & $4.0 \pm 0.3$ & $1.5 \pm 0.4 \mathrm{ab}$ & nd & $0.31 \pm 0.02 b$ \\
\hline & \multirow{3}{*}{ ن } & B & $60.4 \pm 0.4 a$ & $47.0 \pm 0.5 a$ & $0.62 \pm 0.03 a$ & $\mathrm{al}<\mathrm{dl}-7.3$ & $3.8 \pm 0.4 b$ & nd & $0.26 \pm 0.04 a$ \\
\hline & & C & $58.6 \pm 0.5 b$ & $46.0 \pm 0.5 a$ & $0.56 \pm 0.02 b$ & $8.5 \pm 1.2 \mathrm{~b}$ & $1.4 \pm 0.1 \mathrm{c}$ & nd & $0.24 \pm 0.01 \mathrm{a}$ \\
\hline & & D & $58.0 \pm 1.0 \mathrm{~b}$ & $47.5 \pm 1.0 \mathrm{a}$ & $0.46 \pm 0.02 \mathrm{c}$ & $48 \pm 1.9 \mathrm{a}$ & $4.5 \pm 0.2 \mathrm{a}$ & nd & $0.37 \pm 0.08 \mathrm{a}$ \\
\hline & \multirow{3}{*}{$\Xi$} & $\mathrm{C}$ & $73.2 \pm 0.4 a$ & $63.0 \pm 0.8 \mathrm{a}$ & $0.91 \pm 0.01 \mathrm{a}$ & $62 \pm 1.2 \mathrm{a}$ & $6.2 \pm 0.8 \mathrm{a}$ & nd & $0.31 \pm 0.05 b$ \\
\hline & & D & $69.4 \pm 0.5 c$ & $64.0 \pm 1.1 \mathrm{a}$ & $0.63 \pm 0.01 \mathrm{c}$ & $40 \pm 1.2 \mathrm{c}$ & $4.4 \pm 0.2 b$ & nd & $0.33 \pm 0.07 b$ \\
\hline & & $\mathbf{E}$ & $72.1 \pm 0.4 b$ & $64.8 \pm 0.9 \mathrm{a}$ & $0.7 \pm 0.02 \mathrm{~b}$ & $48 \pm 0.8 b$ & $5.8 \pm 0.4 a$ & nd & $0.49 \pm 0.03 a$ \\
\hline
\end{tabular}

TPC* Total phenolic compounds (mg tannic acid equivalent (TAE)/100g FW), AOX** Antioxidant activity ( $\mu$ mol Trolox g-1 FW)

Results represented as Means [ \pm standard deviation (SD)] sharing similar letters in a column (represent three commercial brands, A to E of single product) are statistically non-significant $(P<0.05)$.

Data expressed as mean value \pm SD $(n=3)$. Number of replicates: $\mathrm{n}=3$, FW: fresh weight. 
Table 2. Correlation matrix between tested variables of the commercial products.

\begin{tabular}{llllllll}
\hline Constituent & Vitamin C & TPC & TEAC & $\boldsymbol{\beta}$-carotene & Brix & Acidity & Dry wt. \\
\hline Vitamin C & 1.00 & & & & & & \\
TPC & 0.35 & 1.00 & & & & & \\
TEAC & 0.26 & 0.13 & 1.00 & & & & \\
$\beta$-carotene & 0.01 & 0.08 & 0.06 & 1.00 & & & \\
Brix & 0.29 & 0.53 & 0.18 & 0.22 & 1.00 & & \\
Acidity & 0.14 & 0.44 & 0.04 & 0.17 & 0.68 & 1.00 & \\
Dry wt & 0.29 & 0.50 & 0.14 & 0.25 & 0.98 & 0.48 & 1.00 \\
\hline
\end{tabular}

TPC: Total phenolic content, TEAC: Trolox Equivalent Antioxidant Capacity

\section{Trolox Equivalent Antioxidant Capacity (TEAC)}

The minimum and maximum values of TEAC values nectars made from mango, pineapple and wood apple were $0.23-0.39,0.29-0.38$, and $0.21-0.38$ $\mu$ molTrolox $\mathrm{g}^{-1} \mathrm{FW}$ respectively. The variation resulted was due to the differences in antioxidant capacities in fruit pulp or juice used for nectar production. Similarly, the TEAC values for cordials made from mango, pineapple and wood apple were 0.36-0.58, 0.39-0.58 and 0.23-0.45 $\mu$ molTrolox $\mathrm{g}^{-1}$ FW, respectively (Table 1). The result revealed that fortification has greatly influenced on the TEAC values of the products.

\section{$\beta$-Carotene}

$\beta$-Carotene content in nectar made from mango and pineapple were 1.16-1.24 and 0.64-0.91 $\mu \mathrm{g} / \mathrm{g}$ FW, respectively (Table 1 ). $\beta$-Carotene could not be detected in wood apple nectar, cordial and jam. The pulp of wood apple is dark brown in colour. The fruit is covered with a hard shell, and no yellow-red pigments are available in wood apple pulp. Similarly, $\beta$-carotene in mango and pineapple

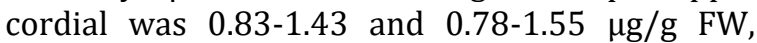
respectively. A substantial amount of $\beta$-carotene was detected in jam products due to higher fruit pulp content ( $40 \%$ ) than other products. Variation in $\beta$-carotene content, $800 \mu \mathrm{g}$ (Mulgoa cultivar), $13,000 \mu \mathrm{g} / \mathrm{g}$ (Alphonso cultivar) (Hymavathi and Khader, 2005) and 1.7-18 $\mu \mathrm{g} / \mathrm{g}$ in different varieties of mango (Rodriguez-Amaya et al., 2008) are reported. $\beta$-Carotene content of processed products substantially reduced during the processing and storage of the product irrespective of the inherent varietal difference of the fruits.

\section{Correlation between Quality Characteristics}

The correlation matrix between tested variables of the market products is given Table 2 . As generally expected, a very high correlation coefficient was established between dry weight and ${ }^{\circ} \mathrm{Bx}\left(\mathrm{R}^{2}=\right.$ 0.98). All the other combinations of correlation coefficients were relatively low and not significantly different $(\mathrm{P}>0.05)$. A lower positive relationship between the antioxidant capacity vs vitamin $C\left(R^{2}=0.26\right)$, and antioxidant capacity vs total phenolic compounds $\left(\mathrm{R}^{2}=0.35\right)$ was observed in the present study. Apparently, the other compounds in the product may contribute significantly to the TEAC value. The highly variable composition of the tested products could be due to the variations in raw material quality, formulation, and the processing technique of nectar, cordial and jam.

However, to improve the nutritional quality and health benefits of these fruit products, a higher level of health beneficial compounds in the products is desirable. Producers can improve this situation by applying strict quality control measures, selection of high-quality raw materials, adapting compatible process control measures and selecting proper storage conditions.

\section{CONCLUSION}

Vitamin, $\beta$-carotene, TPC, TSS and antioxidant activity in nectar, cordial and jam produced from mango, pineapple and wood apple were significantly different $(\mathrm{P}<0.05)$. Vitamin and $\beta$ carotene concentrations were substantially lower or even undetectable in some of the tested products. However, the variation of TSS $\left({ }^{\circ} \mathrm{Bx}\right)$, acidity and dry weight of the tested marketable products were comparatively low because of the compulsory Sri Lanka Standards (SLS) for nectar, cordial and jam. The antioxidant activity of three marketable products of mango, pineapple and wood apple was also significantly different $(\mathrm{P}<0.05)$. The raw materials (fresh fruits or semi processed pulp/juice), history of stored pulp/juice, product formulation, processing techniques, and adherence to the products standards were affected by the compositional variation. Fortification of 
vitamin $\mathrm{C}$ is mostly practiced by the processors and significantly influenced on vitamin C content in fortified products. The correlation coefficients of vitamin $\mathrm{C}$, total phenolics, TEAC, $\beta$-carotene, TSS, acidity and dry weight were comparatively lower. However significant correlation was found inbetween dry weight and TSS $\left(\mathrm{R}^{2}=0.98\right)$, which is a previously known fact. Present consumers prefer more nutritious and healthy fruit pulp or juice based commercial products. However, the influential factors on health beneficial bioactive phytochemicals throughout the supply chain are yet to be investigated in broader perspective. It is recommended to develop nutrient rich new varieties of fruits that can be used to produce high

\section{REFERENCES}

Achinewhu, S,C. and Hart, A, D. (1994). Effect of processing and storage on the ascorbic acid (vitamin C) content of some pineapple varieties grown in the Rivers State of Nigeria. Plant Foods and Human Nutrition. 46, 335-7. https://doi.org/10.1007/BF01088433

Ahn, HY., Cho, HD. and Cho, YS. (2020). Comparison of antioxidant effect and phenolic compounds in tropical fruits. SN Applied Sciences. 2, 1120. DOI: https://doi.org/10.1007/s42452-0202927-5

Ali, S., Haq, C. A. and Hussain. S. (1992) Physicochemical studies of some varieties of mango grown at Shujabad Pakistan Journal of Agricultural. Research 13, 350-356.

AOAC (2000) Official Methods of Analysis of AOAC International, in: Association of Official Analysis Chemists International. DOI: https://doi.org/10.3109/15563657608988 149

Arampath, P. C. and Dekker, M. (2019). Bulk storage of mango (Mangifera indica L.) and pineapple (Ananas comosus L.) pulp: effect of pulping and storage temperature on phytochemicals and antioxidant activity. Journal of the Science of Food and Agriculture. https://doi.org/10.1002/jsfa.9762149

Aune, D., Giovannucci, E., Boffetta, P., Fadnes, L.T., Keum, N., Norat, T., Greenwood, D.C., Riboli, E., Vatten, L.J. and Tonstad, S. (2017). Fruit and vegetable intake and the risk of cardiovascular disease, total cancer and allcause mortality-a systematic review and dose-response meta-analysis of prospective studies. The International Journal of Epidemiology. 46,3,1029-1056. DOI: quality processed food products. Designing of novel products and processes with non-thermal techniques and modern process technologies are essential for the development of commercial fruit products with higher levels of bioactive phytochemicals with health benefits to fulfil the demand of the health-conscious consumers.

\section{AKNOWLEDGEMENT}

Authors acknowledge the financial support granted by the Council for Agricultural Research Policy (CARP), Sri Lanka. Grant No: CARP $/ 12 / 682 / 512$ and the Wageningen University, the Netherlands.

10.1093/ije/dyw319. PMID: 28338764; PMCID: PMC5837313.

Ayala-Zavala, J.F., V. Vega-Vega, C., RosasDomínguez, H., Palafox-Carlos, J.A., VillaRodriguez, M.W., Siddiqui, J.E. Dávila-Aviña. and González-Aguilar, G.A. (2011). Agroindustrial potential of exotic fruit byproducts as a source of food additives, Food Research International 44.7, 1866-1874. DOI: https://doi.org/10.1016/j.foodres.2011.02.0 21

Bushway, R. J. and Wilson, A.M. (1982) Determination of $\alpha$-and $\beta$-Carotene in Fruit and Vegetables by High Performance Liquid Chromatography. Journal of Canadian Institute of Food Science and Technology. 15,165-169.

Bushway, R.J. (1985) Separation of carotenoids in fruits and vegetables by high performance liquid chromatography. Journal of Liguid Chromatography.

8,1527-1547. https://doi.org/10.1080/01483918508067 163

Cárnara, M., Díez, C. and Torija, E. (1995) Chemical characterization of pineapple juices and nectars. Principal components analysis. Food Chemistry. 54, 93-100. https://doi.org/10.1016/03088146(95)92668-A

Casas, R., R. Estruch, and E. Sacanella. 2018. Influence of bioactive nutrients on the atherosclerotic process: A review. Nutrients 10, 11, 1630. DOI: 10.3390/nu10111630.

Chua. L.S. and C.Y. Leong. (2020). Effects of microwave heating on quality attributes of pineapple juice, Journal of Food Processing and Preservation 44, $10 . \quad$ DOI: https://doi.org/10.1111/jfpp.14786 
Colijn, J. M., Buitendijk, G. H. S., Prokofyeva, E., Alves, D., Cachulo, M. L., Khawaja, A. P., Cougnard-Gregoire, A., Merle, B. M. J., Korb, C., Erke, M. G., Bron, A., Anastasopoulos, E., Meester-Smoor, M. A., Segato, T., Piermarocchi, S., de Jong, P., Vingerling, J. R., Topouzis, F., Creuzot-Garcher, C., Bertelsen, G., Pfeiffer, N., Fletcher, A. E., Foster, P. J., Silva, R., Korobelnik, J. F., Delcourt, C. and Klaver, C. C. W. (2017). Prevalence of Age-Related Macular Degeneration in Europe: The Past and the Future. Ophthalmology, 124, 12, 17531763. https://doi.org/10.1016/j.ophtha. 2017.05.035

Crowe-White, K., Parrott, J. S., Stote, K. S., Gutschall, M., Benson-Davies, S., Droke, E., O'Neil, C. E., Wolfram, T. and Ziegler, P. (2017). Metabolic impact of $100 \%$ fruit juice consumption on antioxidant/oxidant status and lipid profiles of adults: An Evidence-Based review. Critical Reviews in Food Science and Nutrition, 57, 1, 152-162. https://doi.org/10.1080/ 10408398.2015.1102861

Da Silva, L.M.R., De Figueiredo, E.A.T., Ricardo, N.M.P.S., Vieira, I.G.P., De Figueiredo, R,W., Brasil I.M. and Gomes, C.L. (2014) Quantification of bioactive compounds in pulps and by-products of tropical fruits from Brazil. Food Chemestry. 143, 398-404. https://doi.org/10.1016/j.foodchem.2013.0 8.001

de Oliveira, A.C., Valentim, I.B., Silva, C.A., Bechara, E.J.H., Barros, M.P., de Mano, C.M. and Goulart, M.O.F. (2009) Total phenolic content and free radical scavenging activities of methanolic extract powders of tropical fruit residues. Food Chemistry. 115, 469-475. https://doi.org/10.1016/j.foodchem.2008.1 2.045

Dekker, M., Verkerk, R. and Jongen, W.M. (2000) Predictive modelling of health aspects in the food production chain: a case study on glucosinolates in cabbage. Trends in Food Science and Technology. 11:174-181. https://doi.org/10.1016/S09242244(00)00062-5

Dekker, M. and Verkerk, R. (2003) Dealing with variability in food production chains: A tool to enhance the sensitivity of epidemiological studies on phytochemicals. Europian Journel of Nutrition. 42, 67-72. https://doi.org/10.1007/s00394-003-04128.

Gonzalez-Gallego, J., M. V. Garcia-Mediavilla, S. Sanchez-Campos, and M. J. Tunon. (2010).
Fruit polyphenols, immunity and inflammation. British Journal of Nutrition 104 (Suppl 3):S15-S27. doi: 10.1017/s0007114510003910.

Gonzalez-Vallinas, M., Gonzalez-Castejon, M., Rodriguez-Casado, A. and Ramirez de A. Molina. (2013). Dietary phytochemicals in cancer prevention and therapy: A complementary approach with promising perspectives. Nutrition Reviews 71, 585-99. DOI: 10.111.nure.12051. https://doi.org/ 10.1002 /(SICI)1097-0010(199802) 76:2<270::AID-JSFA945>3.0.C0;2-9

Hymavathi, T.V. and Khader, V. (2005). Carotene, ascorbic acid and sugar content of vacuum dehydrated ripe mango powders stored in flexible packaging material. Journal of Food Composition and Analysis. 18:181-192. https://doi.org/10.1016/j.jfca.2004.03.028

Jiménez-Escrig, A., Jiménez-Jiménez, I., SánchezMoreno, C. and Saura-Calixto, F. (2000) Evaluation of free radical scavenging of dietary carotenoids by the stable radical 2,2diphenyl-1-picrylhydrazyl. Journal of the Science of Food and Agriculture. 80,16861690. https://doi.org/10.1002/10970010(20000901)80:11<1686::AID-JSFA694 $>3.0 . \mathrm{CO} ; 2-\mathrm{Y}$

Kuskoski, E.M., Asuero, A.G., Morales, M.T. and Fett, R. (2006) Frutos tropicais silvestres e polpas de frutas congeladas: atividade antioxidante, polifenóis e antocianinas. Ciência Rural 36, 1283-1287. https://doi.org/10.1590 /S0103-84782006000400037

Liu ${ }^{a}$, F.X., Fu, S.F., Bi, X.F., Chen, F., Liao, X.J., Hu, X.S. and $\mathrm{Wu}$, J.H. (2013) Physico-chemical and antioxidant properties of four mango (Mangifera indica L.) cultivars in China. Food Chemistry. 138, 396-405. https://doi.org/10.1016/j. foodchem.2012 .09 .111

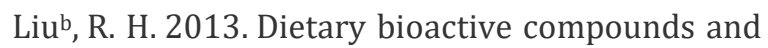
their health implications: Dietary bioactive compounds and health. Journal of Food Science 78, s1: A18-A25. DOI: 10.1111/ 1750-3841.12101.

Lugasi, A. \& Hóvári, J. (2003). Antioxidant properties of commercial alcoholic and nonalcoholic beverages. Nahrung 47, 79-86.

Luximon-Ramma, A., Bahorun, T. and Crozier, A. (2003) Antioxidant actions and phenolic and vitamin C contents of common Mauritian exotic fruits.The Journal of the Science of Food and Agriculture 83,496-502. 
https://doi.org/10.1002/jsfa.1365.

Mahdavi, R., Nikniaz, Z., Rafraf, M. and Jouyban, A. (2010). Determination and Comparison of Total Polyphenol and Vitamin C Contents of Natural Fresh and Commercial Fruit Juices, Pakistan Journal of Nutrition 9, 10. DOI: 10.3923/pjn.2010.968.972

Malta, L.G., Tessaro,E.P., Eberlin, M., Pastore, G.M. and Liu, R.H. (2013). Assessment of antioxidant and antiproliferative activities and the identification of phenolic compounds of exotic Brazilian fruits. Food Research International. 53,417-425. https://doi.org/ 10.1016/j.foodres.2013.04.024

Mohamed, S., Hounhouigan, M., Linnemann, A. and Boekel, M (2014). Effect of Processing on the Quality of Pineapple Juice, Food Reviews International 30 (2014) 112-133. doi: https://doi.org/10.1080/87559129.2014.88 3632

Oboh, G., Ademosun, A.O., Akinleye, M., Omojokun, O.S., Boligon, A.A. and Athayde, M.L. (2015) Starch composition, glycemic indices, phenolic constituents, and antioxidative and antidiabetic properties of some common tropical fruits. Journal of Ethnic Foods 2, 6473.

https://doi.org/10.1016/j.jef.2015.05.003

Ooghe, W. and Dresselaerts, D. (1995). Quality parameters for pineapple juice. Fruit Processing. 5, 11-17.

Pace, G., Lima, P., Vianello, F., Corrêa, C.R., Arnoux, R., Campos, D.S. and Borguini, M.G. (2014) Polyphenols in Fruits and Vegetables and Its Effect on Human Health. Food and Nutrition Sciences. $\quad 5, \quad 1065-1082$. https://doi.org/10.4236/fns.2014.511117

Padda, M.S., do Amarante, C.V.T., Garcia, R.M., Slaughter, D.C. and Mitcham, E.J. (2011) Methods to analyze physico-chemical changes during mango ripening: A multivariate approach. Postharvest Biology Technology. 62:267-274. https://doi.org/10.1016/j.postharvbio.2011 .06 .002

Rodriguez-Amaya, D.B., Kimura, M., Godoy, H.T and Amaya-Farfan, J. (2008) Updated Brazilian database on food carotenoids: Factors affecting carotenoid composition. Journal of Food Composition and Analysis. DOI: 21,445463.https://doi.org/10.1016/j.jfca.2008.04. 001
Sánchez-Moreno, C., Larrauri, J.A. and SauraCalixto, F. (1998) A procedure to measure the antiradical efficiency of polyphenols. Journal of the Science of Food and Agriculture. 76, 270-276.

Saranwong, S., Sornsrivichai, J. and Kawano, S. (2004) Prediction of ripe-stage eating quality of mango fruit from its harvest quality measured nondestructively by near infrared spectroscopy. Postharvest Biology Technology. 31,137-145. https://doi.org/10. 1016/j.postharvbio.2003.08.007

Schreinemachers, P., Simmons, E.B. and Wopereis, M.C.S. (2018). Tapping the economic and nutritional power of vegetables. 16, 36-45.

Siddiq, M., Akhtar, S. and Siddiq, R.(2012). Mango Processing, Products and Nutrition, Tropical and Subtropical Fruits, Postharvest Physiology, Processing and Packaging. 277$297 . \quad$ https://doi.org/10.1002 /9781118324097.ch15

Singleton, V.L., Orthofer, R. and Lamuela-Raventós, R.M. (1998) Analysis of total phenols and other oxidation substrates and antioxidants by means of folin-ciocalteu reagent. Methods in Enzymology. 299,152-178. https://doi.org/10.1016/S0076-6879(99) 99017-1

Somsri, S. (2014). TROPICAL AND SUBTROPICAL FRUIT PRODUCTION IN THAILAND: GAP, International Society for Horticultural Science (ISHS), Leuven, Belgium, 2014, pp. 25-37.

Sri Lanka Standards (SLS) Specification for fruit squashes, fruit syrups and fruit cordials $\left(2^{\text {nd }}\right.$ Revision), SLS 214:2010. Sri Lanka Standards Institution (SLSI), Elvitigala Mawatha, Colombo 08, Sri Lanka.

Sri Lanka Standards (SLS) Specification for jams, jellies and marmalades (2 ${ }^{\text {nd }}$ Rivision), SLS 265:2011. Sri Lanka Standards Institution (SLSI),Elvitigala Mawatha, Colombo 08, Sri Lanka.

Sri Lanka Standards (SLS) Specification for ReadyTo-Serve fruit frinks, Sri Lanka Standards SLS 729:2010 (1 ${ }^{\text {st }}$ Revision),Sri Lanka Standards Institution(SLSI), Elvitigala Mawatha, Colombo 08, Sri Lanka.

Sun, J., Chu, Y.F., Wu, X. and Liu, R.H. (2002) Antioxidant and antiproliferative activities of common fruits. Journal of Agricultural and Food Chemistry. 50, 7449-7454. https://doi.org/10.1021/jf0207530 
Tanaka, T., Shnimizu, M. and Moriwaki, H. (2012) Cancer chemoprevention by carotenoids. Molecules. 17, 3, 3202-42. https://doi.org/10.3390/molecules1703320 2

Thanaraj, T., Terry, L.A. and Bessant, C. (2009) Chemometric profiling of pre-climacteric Sri Lankan mango fruit (Mangifera indica L.). Food Chemistry. 112, 786-794. https://doi.org/10.1016/j.foodchem.2008.0 6.040

Vinson, J.A., Su, X., Zubik, L. and Bose, P.(2001). Phenol antioxidant quantity and quality in foods: Fruits. Journal of Agricultural and Food Chemistry. 49 ,5315-5321. https://doi.org/10.1021/jf0009293
Vollmer, K., Chakraborty, S., Bhalerao, P.P. Carle, R., Frank,J and Steingass, C.B. (2020). Effect of Pulsed Light Treatment on Natural Microbiota, Enzyme Activity, and Phytochemical Composition of Pineapple (Ananas comosus [L.] Merr.) juice, Food and Bioprocess Technology 13,7, 1095-1109. DOI https://doi.org/10.1007/s11947-02002460-7

Wallace, TC., Bailey, RL, Blumberg, JB., BurtonFreeman, B., Chen, CYO., Crowe-White, KM et al. (2020). Fruits, vegetables, and health: A comprehensive narrative, umbrella review of the science and recommendations for enhanced public policy to improve intake. Critical Reviews in Food Science and Nutrition 60, 13, 2174-221. 